\title{
A new locality of Carex pediformis (Cyperaceae) in Poland
}

\author{
Marcin Nobis \& Agnieszka Nobis
}

\begin{abstract}
A new locality of Carex pediformis (Cyperaceae) in Poland. - Acta Mus. Siles. Sci. Natur., 64: 115117, 2015.

Abstract: Carex pediformis C. A. Meyer is a component of dry grasslands (Festucetalia valesiacae order). It is very rare and red-listed in Poland. To date the species is know from less than ten localities in Poland of which four are currently confirmed. The paper presents a data on new locality of the species in the Central Poland (Malopolska Upland), together with remarks on its population size and habitat requirements. The distribution map of the species in Poland is also presented.
\end{abstract}

Key words: distribution, endangered species, habitat requirements, vascular plants

\section{Introduction}

Carex pediformis C. A. Meyer belongs to the section Digitatae (Fr.) Christ., which in the area of Poland additionally includes: Carex digitata L., C. ornithopoda Willd., C. pallidula Harmaja, C. humilis Leyss. The main characteristics typical to aforementioned species include: solitary male spike, relatively loosely arranged female spikes, a large and more or less leaflike lowermost bract and ovoid and usually puberulent utricles.

Carex pediformis is a native species representing an Euro-Siberian sub-element in the Polish flora (Hultén \& Fries 1986). In Europe, its westernmost stations are located in Poland, Czech Republic and Austria (Hultén \& Fries 1986, Towpasz 1969, Bąba 2014).

Carex pediformis is a component of dry grasslands developed on calcareous rocks of river valleys slopes. The patches of grasslands with this species usually cover small areas and are currently highly threatened by successional processes. The species has been included as critically endangered in the national red list of vascular plants (Zarzycki \& Szeląg 2006) and in the Polish red data book of plants (Bąba \& Biderman 2001, Bąba 2014).

Currently, Carex pediformis has been confirmed at three localities in Poland, namely: Będkowska River Valley (Kosiński 1992, Nobis et al. 2010 unpbl.), Ojców National Park (Michalik 1978, Nobis et al. 2010-2013 unpbl., Bąba 2014) and Podgrodzie in the Kamienna River Valley (Piotrowski 1897, Piwowarczyk \& Nobis 2005, Nobis M. 2014 unpbl.). It is worth to note, that in the Ojców National Park, numerous population of the species has been observed at few localities between Grodzisko and Wdowie Rocks and on Krzyżowa Rock (Nobis et al. unpbl, Bąba 2014). The presence of the species in Zapusty near Cząstków in the Śwętokrzyskie Mts. (Kobendza 1947, Kapuściński 1990) need to be confirmed. Whereas the localities in Przystroń near Niemcza on Lower Silesia and Gacki near Ujazd (Towpasz 1969, 1996) are probably only of historic value.

\section{New locality}

During the excursion in Zarzecze settlement near Bałtów village, ca. $12 \mathrm{~km} \mathrm{NE}$ of Ostrowiec Świętokrzyski (Atpol greed of squares $2.5 \mathrm{~km}$ x $2.5 \mathrm{~km}$ - Zając 1978: FE 50 23; Fig. 1) in the summer of 2014, we found few individuals of Carex pediformis. In May 2015, we decided to explore this new locality once again, to answer the question: how numerous is the population of the species, where it occurs (in which plant communities) and what is the are of its occurrence. 


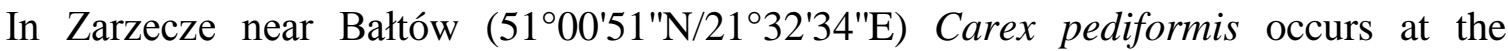
bottom, on shelves and on the top of calcareous rocks at right slope of the Kamienna River Valley, at the are of ca. $250 \mathrm{~m}^{2}$. Population of the species is quite numerous, it comprises over 500 tufts and over half of them flourished and had fruits. At the new locality, C. pediformis grows within dry grassland (Festucetalia valesiacae order), on the outskirts and within light bushes (Peucedano cervariae - Coryletum) and on rock shelves (Festucetum pallentis). The population is threatened due to secondary succession involving with expansion of bushes species. However, it is worth to mentioned, that Bałtów is a touristic place and for a receiving better view on beautiful calcareous rocks in this place, frequently visited by tourists, the trees and shrubs were recently cut out and rocks have been exposed to the light. It was very helpful to population of $C$. pediformis, which due to improvement of habitat conditions strongly connected with the availability of light, was rapidly enlarged number of individuals and area covered by this species.

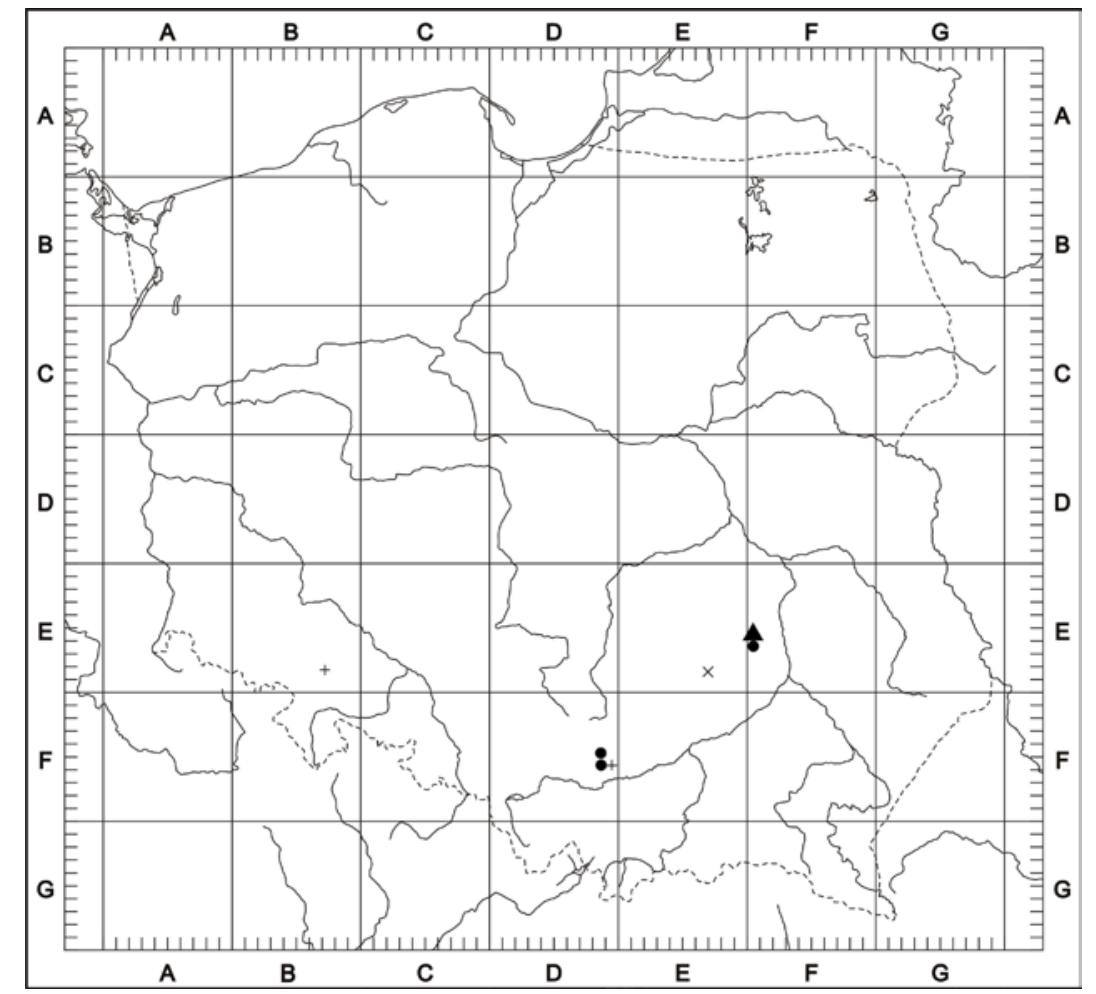

Fig 1: Distribution of Carex pediformis C. A. Meyer in Poland; $\mathbf{x}$ - station not confirmed at present; + - probably extinct station.

\section{References}

Bąba W. (2015): Carax pediformis C. A. Meyer. - In: Kaźmierczakowa R., Zarzycki K. \& Mirek Z. [eds]: Polish Red Data Book of Plants, pp. 715-716. Instytut Ochrony Przyrody, PAN, Kraków.

Bąba W. \& Biderman A.W. (2001): Carax pediformis C. A. Meyer. - In: Kaźmierczakowa R. \& Zarzycki K. [eds]: Polish Red Data Book of Plants, pp. 513-514. Instytut Botaniki im. W. Szafera i Instytut Ochrony Przyrody, Polska Akademia Nauk, Kraków.

Hultén E. \& Fries M. (1986): Atlas of north European vascular plants north of the Tropic of Cancer. - Koeltz Scientific Books, Königstein.

Kapuściński R. (1990): Zmiany roślinności kserotermicznej w projektowanym rezerwacie „Zapusty” w warunkach ograniczonej ingerencji człowieka. - Prądnik. Prace Muz. Szafera 2: 23-27.

Kobendza R. (1947): Projekt rezerwatu na ściankach łupkowych w Cząstkowie koło Góry Chełmowej w Górach Świętokrzyskich. - Chrońmy Przyr. Ojcz. 3(5-6): 31-34. 
Kosiński M. (1992): Flora naczyniowa skał, muraw i zarośli kserotermicznych Doliny Będkowskiej. Pradnik. Prace Muz. Szafera 5: 109-148.

Michalik S. (1978): Rośliny naczyniowe Ojcowskiego Parku Narodowego. - Stud. Nat., Ser. A 16: 1-171.

Piotrowski K. (1897): Korespondencja Wszechświata. - Wszechświat 16: 477-478.

Piwowarczyk R. \& Nobis M. (2005): Stanowisko Carex pediformis (Cyperaceae) w Podgrodziu koło Ćmielowa. Fragm. Flor. Geobot. 12(1): 181-183.

Towpasz K. (1969): Rozmieszczenie Carex pediformis C. A. Mey. w Polsce i krajach ościennych. Fragm.Flor. Geobot. 15: 9-12.

- (1996): Flora roślin naczyniowych doliny Kluczwody. - Fragm. Flor. Geobot. Ser. Polonica 3: 141-187.

Zając A. (1978): Założenia metodyczne „Atlasu rozmieszczenia roślin naczyniowych w Polsce”. - Wiad. Bot. 22(3): 145-155.

Authors' addresses: Marcin Nobis \& Agnieszka Nobis, Department of Plant Taxonomy, Phytogeography and Herbarium, Institute of Botany, Jagiellonian University, Kopernika 27, 31-501 Kraków, Poland. E-mail of corresponding author: m.nobis@uj.edu.pl
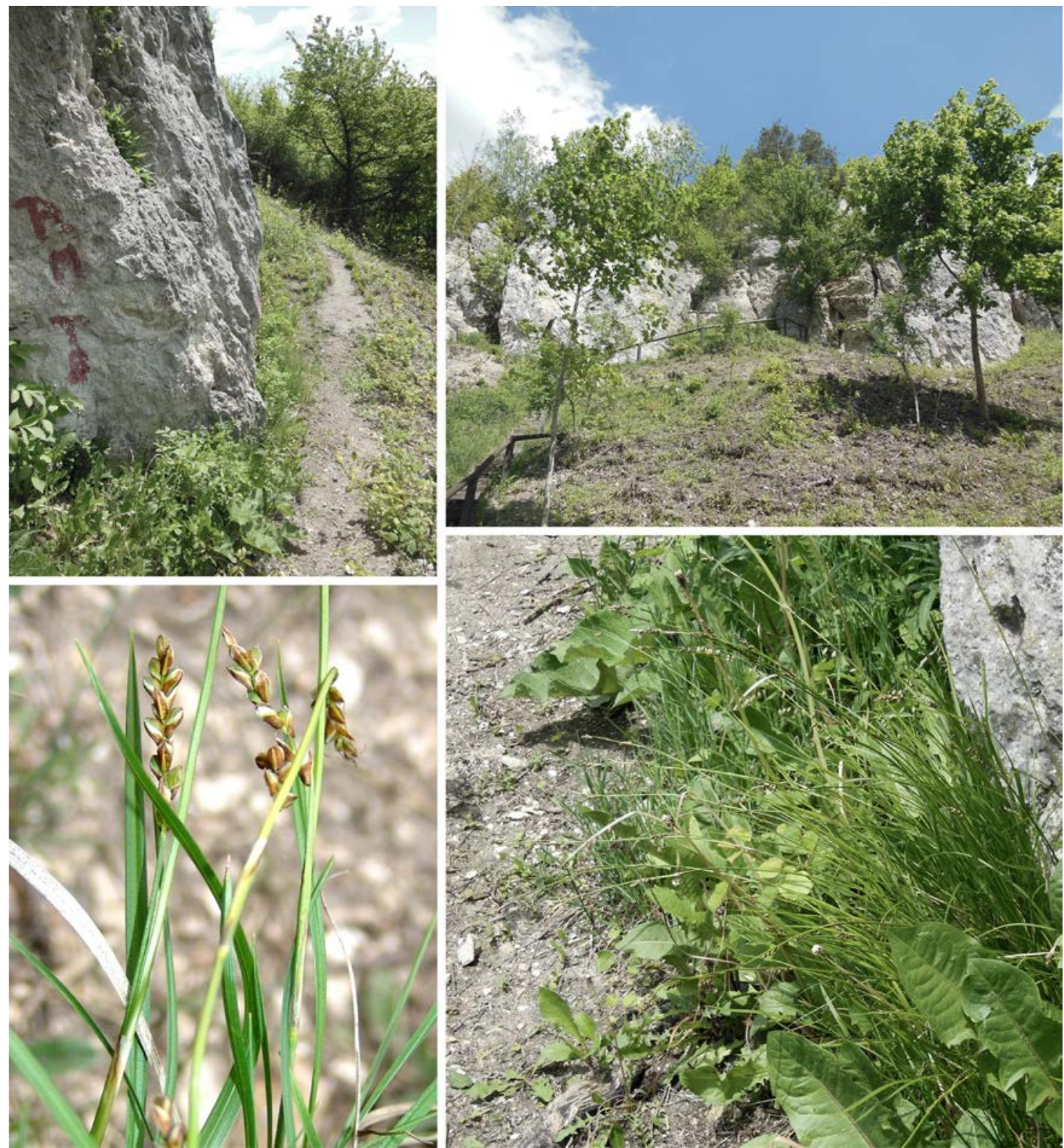

Fig 2: Carex pediformis C. A. Meyer in Zarzecze near Bałtów. 